\title{
The Effect of Planting Periods on Yield and Quality of Fresh Tomatoes Produced in an Open Field under Rain Fed
}

\author{
Dessie Getahun Engida
}

Ethiopian Institute of Agricultural Research (EIAR), Fogera Research Center

\begin{abstract}
Seasonality in tomato production in Ethiopia is causing discrepancy in supply and demand for fresh tomatoes. Despite the importance of tomatoes in the daily diet of the people and ever increasing demand throughout the year, tomatoes are not produced during the rainy periods and fresh tomato supply is limited and the price climbs up. Stressing on continuous production throughout the year and concomitant constant supply of fresh tomatoes, different planting periods were evaluated for productivity and fruit quality of two improved varieties. Randomized complete block design in split plot arrangement in three replications was used. Transplanting in the onset (June), middle (July) and end (August) of the rainy season were considered main plots whereas varieties Melkashola and Melkasalsa as sub plots. Interactions, except year and transplanting time, were found non significant while respective main effects were significantly different in marketable fresh and nonmarketable tomato yields. Significantly $(P<0.01)$ highest marketable fresh tomato yield was obtained from transplanting in the middle (July) of the rainy season $\left(126.55 \mathrm{~kg} / 30 \mathrm{~m}^{2}\right)$ of 2005 . High early harvest was made from variety Melkasalsa whereas total marketable yield is high for variety Melkashola. On the other hand, percentage nonmarketable yield was significantly high from transplanting in the end (August) of the rainy season. It is proven that tomatoes can be produced throughout the year even in the rainy seasons. Although high yield with good quality tomatoes are produced in the rainy season, further effort is required, with the use of appropriate IDM practices, to minimize the proportion of nonmarketable tomatoes.
\end{abstract}

Keywords: Dry season, IDM, nonmarketable, transplanting.

\section{INTRODUCTION}

Tomatoes (Lycopersicon esculentum Mill.) are the second most important vegetable in economic importance and consumption in the world, second only to potatoes (Ibitoye et. al, 2009). They are used as fresh vegetable, and processed and canned as a paste, sauce, ketchup and juice (Muhammad \& Singh, 2007). Tomatoes can be eaten raw in salads or cooked, fried or sundried (ARC, 2013). From processing to fresh market, and from sauce to juice and salad, the variety and usefulness of the fruit is virtually boundless.

Tomato production is a remunerative business for smallholder as well as commercial farmers in Ethiopia. It is also the highest vegetable income earner in Kenya (Kirimi et. al, 2011). Tomatoes are conventionally grown in an open field during the dry periods using irrigation. On the other hand, rain fed tomato production in an open field was considered difficult mainly because of disease attack leading to complete destruction of tomato plants. Seasonality in tomato production and concomitantly abundance and scarcity in supply is reflected, bringing about discrepancy in supply and demand for fresh tomatoes.

Despite the importance of tomatoes in the daily diet of the people and ever increasing demand for this crop, fresh tomatoes supply during the rainy period is limited and the price climbs up. Critical periods when tomato supply is of serious shortage around Fogera is from June through November. Fluctuations in the supply of tomatoes in the Kenyan market leading to market glut during in season and shortage during off season was also reported by Kirimi et. al (2011). According to Panday et. al (2005), tomato crop in India is severely damaged by damping off, bacterial blight, alternaria blight and tomato leaf curl virus. Major tomato diseases during the rainy period around Fogera in Ethiopia include late blight (Phytophthora infestans), early blight (Alternaria solani), septoria leaf spot (Septoria lycopersici), fusarium wilt (Fusarium oxysporum), bacterial wilt (Rlstonia solanacearum formerly known as Pseudomonas solanacearum), powdery mildew (Leveillula taurica (Oidiopsis taurica), Erysiphe orontii ( E. cichoracearum and E. polyphaga)) and viral diseases such as tomato 
yellow leaf curl virus (TYLCV) and tomato spotted wilt virus (TSWV) (Getahun, 2015). These diseases could be controlled or mitigated through the use of integrated disease management (IDM). Successful tomato production during the rainy season has been demonstrated at Fogera using regular fungicide spraying (with Agrolaxyl, Ridomil and Mancozeb) as part and parcel of key practices of IDM. According to Greenwald (2013), based on Cornell University Cooperative Extension, it is impossible to control late blight on a plant if " $5-10 \%$ of the foliage is infected." Preventive spray is thus essential to limit the severity of disease outbreaks.

The importance of integrated disease management practice for rain fed tomato production is crucial. IDM package, according to Panday et.al (2005) in nursery beds comprised soil solarization, use of neem cake, bioagents application, nylon netting and streptocycline spray. Tomato production in the rain season requires attentive daily follow up of both the plant as well as the weather conditions. Control measures include the use of resistant varieties, seeds free from pathogens, seed treatment, improved drainage, proper sanitation, keeping cultivated fields clean free from weeds and other foreign material that can serve as host for the pathogens. Destroying infected plants and throwing them away from the field, the use of registered chemicals and crop rotation are also vital. According to Shamiyeh, et.al (2001) the major commercial control strategies for both early and late blight have been a preventive spray program with fungicide applications made on seven day schedule depending on weather conditions. Frequent fungicide applications, usually on a seven to ten day schedule, are imperative for acceptable disease control and successful tomato production in the rainy season.

Site selection is also an important initial step for IDM. The use of well drained soil which has not been used for tomato and similar crops production in the last two to three years is advised. Tomatoes benefit from crop rotation. It is critical to avoid planting tomato in a field planted the previous season with tomato, pepper, eggplant, or other solanaceous crop. These crops share some insect and disease problems. Crop rotation can avoid some diseases, and keep fertility. A three-to four year-rotation program with non-related crops is recommended to reduce build-up of pests and diseases. Ridging and staking are also crucial specifically to drain excess water and to keep the foliage and fruit off the ground, respectively. Supporting tomato plants using stick, bamboo, wire and/or rope, in addition to avoiding foliage and fruit contact with the soil, allows good air movement around the plants, allows for more uniform spray coverage, improves fruit quality and makes harvesting easier.

Constant supply of fresh tomatoes throughout the year requires an uninterrupted production both in the dry and rainy seasons. Aiming to ensure continuous production and constant supply of fresh tomatoes, this study was undertaken to evaluate planting periods on productivity and fruit quality of tomato varieties in the rainy season.

\section{MATERIAL AND MethodS}

\subsection{Description of the location}

Field experiments were carried out at Fogera Agricultural Research Center for two successive rainy seasons, from May to November 2015 and 2016. The Center is located at the south periphery of Woreta town of Fogera district of South Gondar Administrative zone in Amhara Region, Ethiopia. Woreta lies at $11^{\circ} 58^{\prime} \mathrm{N}$ latitude and $37^{\circ} 41^{\prime} \mathrm{E}$ longitude. It has an altitude of $1819 \mathrm{~m}$ above sea level and receives average annual rainfall of $1230 \mathrm{~mm}$. Mean minimum and maximum temperature of the area is 12 and $28^{\circ}$, respectively. The soil is red clay (vertisol) rich in underground water.

\subsection{Treatment and Seedling Raising}

Treatments were transplanting periods with three levels, i.e, transplanting in the onset (June), middle (July) and end (August) of the rainy season. Varieties used were Melkashola and Melkasalsa. The experimental design employed was randomized complete block with a split-plot arrangement in three replications, planting periods considered main plots and varieties as sub plots. Total and effective plot size of $80 \mathrm{~m}^{2}$ and $60 \mathrm{~m}^{2}$, respectively was used as main plots. An effective size of the sub plot was 30 $\mathrm{m}^{2}$, while the total size is $40 \mathrm{~m}^{2}$.

Seeds of tomato varieties Melksalsa and Melkshola were obtained from Melkassa Agricultural Research centre of the Ethiopian Institute of Agricultural Research. Seeds for 2016 experiment were sown on 19 May, 16 June and 14 July 2016, respectively, for June, July and August transplanting, while seeds for 2015 experiment were sown on May 21, June 23, and July 25, 2015. Seedlings of each variety were raised on $5 \mathrm{~m} \times 1 \mathrm{~m}$ thoroughly prepared beds, $5 \mathrm{~cm}$ raised from the surface. Seeds were 
drilled on rows with ten $\mathrm{cm}$ inter-row spacing and it was covered lightly with fine soil and mulched with eucalyptus leaves until emergence. Grass or straw mulching is not advised because it aggravates termite damage around the study area. Seedlings were thinned at first true leaf stage to allow 2-3 cm distance within plants (intra-raw spacing). Seedlings were raised under white plastic cover to avoid rain contact with foliage of seedlings. Plastic cover is made at about $75 \mathrm{~cm}$ height from the surface of the seed bed. Watering using watering cans was made just on the soil surface caring to avoid moisture contact with seedling leaves. Weeding was accomplished as deemed necessary.

\subsection{Land Preparation and Transplanting}

Experimental plot was thoroughly plowed and leveled. Ridges were prepared with $25 \mathrm{~cm}$ height from the furrow. Transplanting was done at sides of ridges with $40 \mathrm{~cm}$ spacing between plants and $100 \mathrm{~cm}$ inter-row spacing. The size of the sub plot is $40 \mathrm{~m}^{2}$ and the main plot is $80 \mathrm{~m}^{2}$. One meter walk way was used in between plots and blocks. Healthy, vigorous and uniform transplantable pencil size seedlings were obtained after four weeks of seedling age and transplanting was carried on sides of ridges on 27 June, 25 July and 23 August 2016 and on June 24, July 22 and August 20, 2015 for the first, second and third transplanting of 2016 and 2015 rainy seasons, respectively. Replanting to replace dead or weak seedlings in field establishment was done a week from transplanting.

\subsection{Field Management}

Inorganic fertilizers in the form of Diamonnuim phosphate (DAP) (18:46:0) and urea (46:0:0) were applied at the rate of 150 and $100 \mathrm{~kg} / \mathrm{ha}$ (kilogram per hectare), respectively. DAP was applied at transplanting while urea was applied in two splits, the first at transplanting and the second 11/2 months from transplanting. Standard field management practices such as weeding and cultivation was performed uniformly during the growing seasons for all planting periods. Supplementary irrigation water was not applied to either of the two year trials.

Prior to flower initiation stage, staking was made to tomato plants using stick and rope. Starting from two weeks after transplanting until fruit setting stage, fungicide spraying against diseases were made at seven to ten days interval depending on the weather condition. Agrolaxyl (3 kg/ha) and Ridomil Gold Mz 68 WG (3kg/ha) were alternatively sprayed. Spraying was done after thoroughly mixing fungicides in 500-700 liters water per hectare. Moreover, as a strategy to minimize wind dispersal of inoculums of pathogens from one plot to the other, two rows of rice were grown in the gangways in between main plots and blocks . Furthermore plants with symptoms of virus infection were rouged out and buried.

\subsection{Data Collection}

Data collection was done on disease incidence, plot cover, flower initiation and days to fifty percent flowering. Plant height was measured at 50\% flowering stage. Visual judgment is made to record the proportion of the plot surface covered by tomato foliage. Number of days required from transplanting date to the day on which 50\% of the plants in a plot flowered was recorded. Out of four ridges of each $40 \mathrm{~m}^{2}$ subplots, yield data was collected only from the inner three ridges $\left(30 \mathrm{~m}^{2}\right)$. Fruit yield was harvested at appropriate maturity time (at early light red to red or ripe stages). Five consecutive harvests at a week interval were made from a single plot. Each harvest from a plot was immediately sorted out for marketable and non marketable fruits. Marketable fruits are those with average size and above, and are free from visible damages due to diseases, insects and physiological disorder. Marketable fruits were counted and weighed whereas nonmarketable fruits were counted and sorted out based on their respective causes, i.e., diseases, insects, physiological disorder or undersized fruits. Percentage fruit loss (nonmarketable fruits) was calculated as total number of nonmarketable fruits multiplied by 100 and divided by total number of tomato fruits (marketable and nonmarketable fruits). Data was subjected to analysis of variance using SAS software and list significance difference was used to compare treatment means when there was statistically significant difference $(\mathrm{P}<0.05)$.

\section{RESULT AND DISCUSSION}

The interaction between transplanting time and variety was not significant while respective main effects namely, transplanting time and variety showed significant difference in marketable fresh tomato yield for both harvests from first to fifth (total) harvest (Table 1). In year 2015, for harvests from first to the fourth, transplanting in the middle of the rainy season (July transplanting) produced significantly higher $(\mathrm{P}<0.01)$ marketable fresh tomato yield than transplanting in June (in the onset) and August (in the end of the rainy season). On the other hand, in 2016 rainy season, significantly 
high marketable fresh tomato yield was obtained from transplanting in the onset (June) of the rainy season (Table 2). In all harvests, except total marketable yield (five harvests) in 2015, variety Melksalsa out yielded variety Melkashola both in 2015 and 2016 rainy seasons (Table 1 \& 2). Variety Melkasalsa is thus preferred to Melkashola for early harvest as well as consistent high yield. Davis and Estes (1993) reported that high net returns can be obtained by producing high early-season yields when prices are high.

Table 1. Mean marketable fresh tomato yield (in $\mathrm{kg} / 30 \mathrm{~m}^{2}$ plot) in 2015 rainy season

\begin{tabular}{|l|l|l|l|l|l|l|}
\hline Treatment & $\begin{array}{l}\text { First } \\
\text { harvest }\end{array}$ & $\begin{array}{l}\text { Two } \\
\text { harvests }\end{array}$ & $\begin{array}{l}\text { Three } \\
\text { harvests }\end{array}$ & $\begin{array}{l}\text { Four } \\
\text { harvests }\end{array}$ & $\begin{array}{l}\text { Total yield (five } \\
\text { harvests) }\end{array}$ \\
\hline \multirow{2}{*}{$\begin{array}{l}\text { Transplanting } \\
\text { time }\end{array}$} & Onset (June) & $7.994^{\mathrm{c}}$ & $29.486^{\mathrm{b}}$ & $54.244^{\mathrm{b}}$ & $80.36^{\mathrm{b}}$ & $102.67^{\mathrm{ab}}$ \\
\cline { 2 - 7 } & Middle (July) & $23.752^{\mathrm{a}}$ & $61.002^{\mathrm{a}}$ & $97.435^{\mathrm{a}}$ & $116.00^{\mathrm{a}}$ & $126.55^{\mathrm{a}}$ \\
\cline { 2 - 7 } & End (August) & $15.205^{\mathrm{b}}$ & $30.638^{\mathrm{b}}$ & $52.522^{\mathrm{b}}$ & $73.72^{\mathrm{b}}$ & $93.02^{\mathrm{b}}$ \\
\cline { 2 - 7 } & LSD & 6.02 & 10.35 & 18.55 & 24.76 & 29.95 \\
\hline \multirow{3}{*}{ Variety } & Melkasalsa & $19.659^{\mathrm{a}}$ & $47.765^{\mathrm{a}}$ & $75.637^{\mathrm{a}}$ & $91.393^{\mathrm{a}}$ & $100.37^{\mathrm{a}}$ \\
\cline { 2 - 7 } & Melkashola & $11.641^{\mathrm{b}}$ & $32.985^{\mathrm{b}}$ & $62.497^{\mathrm{a}}$ & $89.197^{\mathrm{a}}$ & $114.45^{\mathrm{a}}$ \\
\cline { 2 - 7 } & LSD & 4.91 & 8.45 & 15.15 & 20.21 & 24.45 \\
\hline & $\mathrm{CV} \%$ & 29.9 & 19.9 & 20.9 & 21.3 & 21.7 \\
\hline Interaction & $\mathrm{T}^{*} \mathrm{~V}$ & $\mathrm{NS}$ & $\mathrm{NS}$ & $\mathrm{NS}$ & $\mathrm{NS}$ & $\mathrm{NS}$ \\
\hline
\end{tabular}

$\mathrm{NS}=$ non significant at $0.05, \mathrm{~T}=$ transplanting time, $\mathrm{V}=$ variety; Means in a column followed by the same letter within a treatment group are not significantly different at $\mathrm{P}<0.05$

Harvest one is the first harvest while harvest two indicates total yield from first and second harvests. Harvest three is a total yield from $1^{\text {st }}, 2^{\text {nd }}$ and third harvests, and so on.

Table 2. Mean marketable fresh tomato yield (in $\mathrm{kg} / 30 \mathrm{~m}^{2}$ plot) in 2016 rainy season

\begin{tabular}{|l|l|l|l|l|l|l|}
\hline \multicolumn{2}{|l|}{ Treatment } & $\begin{array}{l}\text { First } \\
\text { harvest }\end{array}$ & $\begin{array}{l}\text { Two } \\
\text { harvests }\end{array}$ & $\begin{array}{l}\text { Three } \\
\text { harvests }\end{array}$ & $\begin{array}{l}\text { Four } \\
\text { harvests }\end{array}$ & $\begin{array}{l}\text { Total yield (five } \\
\text { harvests) }\end{array}$ \\
\hline \multirow{3}{*}{$\begin{array}{l}\text { Transplanting } \\
\text { time }\end{array}$} & Onset (June) & $4.60^{\mathrm{a}}$ & $14.975^{\mathrm{a}}$ & $36.625^{\mathrm{a}}$ & $54.942^{\mathrm{a}}$ & $62.208^{\mathrm{a}}$ \\
\cline { 2 - 7 } & Middle (July) & $2.55^{\mathrm{b}}$ & $7.667^{\mathrm{b}}$ & $15.85^{\mathrm{b}}$ & $26.767^{\mathrm{b}}$ & $34.709^{\mathrm{b}}$ \\
\cline { 2 - 7 } & End (August) & $3.66^{\mathrm{ab}}$ & $9.245^{\mathrm{b}}$ & $20.044^{\mathrm{b}}$ & $31.012^{\mathrm{b}}$ & $41.895^{\mathrm{b}}$ \\
\cline { 2 - 7 } & LSD & 1.72 & 4.39 & 7.05 & 7.72 & 12.07 \\
\hline \multirow{4}{*}{ Variety } & Melkasalsa & $4.326^{\mathrm{a}}$ & $12.75^{\mathrm{a}}$ & $22.975^{\mathrm{a}}$ & $40.237^{\mathrm{a}}$ & $47.042^{\mathrm{a}}$ \\
\cline { 2 - 7 } & Melkashola & $2.882^{\mathrm{b}}$ & $8.50^{\mathrm{b}}$ & $20.371^{\mathrm{b}}$ & $34.909^{\mathrm{a}}$ & $45.50^{\mathrm{a}}$ \\
\cline { 2 - 7 } & LSD & 1.405 & 3.58 & 5.76 & 6.3 & 9.86 \\
\hline & $\mathrm{CV} \%$ & 37.95 & 32.79 & 22.28 & 15.96 & 20.28 \\
\hline Interaction & $\mathrm{T} \mathrm{V}$ & $\mathrm{NS}$ & $\mathrm{NS}$ & $\mathrm{NS}$ & $\mathrm{NS}$ & NS \\
\hline
\end{tabular}

$\mathrm{NS}=$ non significant at $0.05, \mathrm{~T}=$ transplanting time, $\mathrm{V}=$ variety; Means in a column followed by the same letter within a treatment group are not significantly different at $\mathrm{P}<0.05$

Combined analysis of data of two years revealed that except the interaction between year and transplanting time, all other interactions were not significantly different in marketable fresh tomato yield. When compared with yield in 2015 rainy season, marketable fresh tomato yield was generally low in 2016. In contrast to 2015 when rainfall was not beyond sufficient (due to ELINO), heavy rainfall prevailed in 2016 particularly in July and August. Consequently, it was observed that excess rain water was standing in furrows for few minutes to hours. This is believed to favor disease attack and restrict plant growth, ultimately bringing about low marketable yield. Heavy rain fall and cloud cover interfered with light penetration thereby affecting metabolic activity of tomato plants. Kris (2010) reported that tomato patch should be in full sun. According to Tabasi et.al (2013) more light penetration into the canopy increases photosynthetic activity thereby increasing fruit quality (total soluble solid) and yield. Sunlight is a crucial factor on fruit quality, and further showed that more light penetration to the plant increases ascorbic acid, lycopene and carotenoids. Likewise cold temperature is recorded from September through December particularly in early morning and night in 2016 (as compared with 2015). Since tomato plants are warm season vegetables that enjoy high temperature within the limit of the crop requirement, cold temperature could be attributable to low yield and poor quality in 2016. Variety Melksalsa, however demonstrated considerable cold tolerance in 2016. Kirimi et.al (2011) showed that low temperatures $\left(<16\right.$ to $\left.19^{\circ} \mathrm{C}\right)$ limit production of tomatoes while the optimal temperature for tomatoes is 21 to $24^{0} \mathrm{C}$. 
The effect of planting periods on yield and quality of fresh tomatoes produced in an open field under rain fed

Table 3. Combined mean fresh marketable yield (in $\mathrm{kg} / 30 \mathrm{~m}^{2}$ plot) of tomatoes from 2015 and 2016 rainy seasons

\begin{tabular}{|l|l|l|l|l|l|l|}
\hline \multicolumn{2}{|l|}{ Treatment } & $\begin{array}{l}\text { First } \\
\text { harvest }\end{array}$ & $\begin{array}{l}\text { Two } \\
\text { harvests }\end{array}$ & $\begin{array}{l}\text { Three } \\
\text { harvests }\end{array}$ & $\begin{array}{l}\text { Four } \\
\text { harvests }\end{array}$ & $\begin{array}{l}\text { Total yield (five } \\
\text { harvests) }\end{array}$ \\
\hline \multirow{3}{*}{$\begin{array}{l}\text { Transplanting } \\
\text { time }\end{array}$} & Onset (June) & $6.297^{\mathrm{b}}$ & $22.23^{\mathrm{b}}$ & $45.435^{\mathrm{ab}}$ & $67.651^{\mathrm{ab}}$ & $82.44^{\mathrm{a}}$ \\
\cline { 2 - 7 } & Middle (July) & $13.151^{\mathrm{a}}$ & $34.334^{\mathrm{a}}$ & $56.643^{\mathrm{a}}$ & $71.784^{\mathrm{a}}$ & $80.629^{\mathrm{a}}$ \\
\cline { 2 - 7 } & End (August) & $9.433^{\mathrm{ab}}$ & $19.942^{\mathrm{b}}$ & $37.783^{\mathrm{b}}$ & $52.367^{\mathrm{b}}$ & $67.458^{\mathrm{a}}$ \\
\cline { 2 - 7 } & LSD & 4.227 & 8.351 & 12.17 & 16.11 & 18.157 \\
\hline \multirow{5}{*}{ Variety } & Melkasalsa & $11.993^{\mathrm{a}}$ & $30.26^{\mathrm{a}}$ & $51.806^{\mathrm{a}}$ & $65.815^{\mathrm{a}}$ & $73.708^{\mathrm{a}}$ \\
\cline { 2 - 7 } & Melkashola & $7.261^{\mathrm{b}}$ & $20.745^{\mathrm{b}}$ & $41.434^{\mathrm{b}}$ & $62.053^{\mathrm{a}}$ & $79.977^{\mathrm{a}}$ \\
\cline { 2 - 7 } & $\mathrm{LSD}$ & 3.45 & 6.819 & 9.94 & 13.155 & 14.83 \\
\hline \multirow{3}{*}{ Year } & $\mathrm{V}^{*} \mathrm{~T}$ & $\mathrm{NS}$ & $\mathrm{NS}$ & $\mathrm{NS}$ & $\mathrm{NS}$ & $\mathrm{NS}$ \\
\cline { 2 - 7 } & 2015 & $15.65^{\mathrm{a}}$ & $40.375^{\mathrm{a}}$ & $69.067^{\mathrm{a}}$ & $90.295^{\mathrm{a}}$ & $107.414^{\mathrm{a}}$ \\
\cline { 2 - 7 } & 2016 & $3.604^{\mathrm{b}}$ & $10.629^{\mathrm{b}}$ & $24.173^{\mathrm{b}}$ & $37.573^{\mathrm{b}}$ & $46.271^{\mathrm{b}}$ \\
\cline { 2 - 7 } & $\mathrm{LSD}$ & 3.452 & 6.819 & 9.94 & 13.155 & 14.825 \\
\hline \multirow{3}{*}{ Interaction } & $\mathrm{T}^{*} \mathrm{Y}$ & $\mathrm{S}$ & $\mathrm{S}$ & $\mathrm{S}$ & $\mathrm{S}$ & $\mathrm{S}$ \\
\cline { 2 - 7 } & $\mathrm{V}^{*} \mathrm{Y}$ & $\mathrm{NS}$ & $\mathrm{NS}$ & $\mathrm{NS}$ & $\mathrm{NS}$ & $\mathrm{NS}$ \\
\cline { 2 - 6 } & $\mathrm{T}^{*} \mathrm{~V}^{*} \mathrm{Y}$ & $\mathrm{NS}$ & $\mathrm{NS}$ & $\mathrm{NS}$ & $\mathrm{NS}$ & $\mathrm{NS}$ \\
\hline & $\mathrm{CV} \%$ & & 38.86 & 30.8 & 29.76 & 27.9 \\
\hline
\end{tabular}

$\mathrm{NS}=$ non significant, $\mathrm{S}=$ significant, $\mathrm{T}=$ transplanting time, $\mathrm{V}=$ variety, $\mathrm{Y}=$ year; Means in a column followed by different letter within a treatment group are significantly different at $\mathrm{P}<0.05$

Transplanting in the middle (July) of the rainy season performed superior than transplanting in the onset (June) and end (August) of the rainy season when the rain fall is light but not insufficient. On the other hand, during a season of heavy rain fall (2016), transplanting in the onset (June) followed by in the end (August) of the season performed better than transplanting in the middle (July) of the rainy season. According Kris (2010), tomatoes can grow year round, though dry season crops are definitely much easier to deal with; the humidity of the wet season can cause so many problems.

The highest percentage nonmarketable tomato yield was recorded from the first harvest and this is largely due to premature fruit drop caused by rain fall and diseases. In harvest one and successive three harvests significantly high percentage of nonmarketable fruit yield was recorded from transplanting in the end of the rainy season (August) while transplanting times were not significantly different in percentage nonmarketable fruits for the last two harvests ( the sum of four and five harvest (total yield)) (Table 4).

Table 4. Combined percent non marketable yield of 2015 and 2016

\begin{tabular}{|c|c|c|c|c|c|c|}
\hline \multicolumn{2}{|l|}{ Treatment } & \multirow{2}{*}{$\begin{array}{l}\text { Harvest } 1 \\
49.63^{\mathrm{a}}\end{array}$} & \multirow{2}{*}{$\begin{array}{l}\begin{array}{l}\text { Two } \\
\text { harvests }\end{array} \\
41.12^{\mathrm{a}}\end{array}$} & \multirow{2}{*}{$\begin{array}{l}\text { Three } \\
\text { harvests }\end{array}$} & \multirow{2}{*}{$\begin{array}{l}\text { Four } \\
\text { harvests } \\
39.65^{\mathrm{a}}\end{array}$} & \multirow{2}{*}{$\begin{array}{l}\text { Total yield (Five } \\
\text { harvests) } \\
44.38^{\mathrm{a}} \\
\end{array}$} \\
\hline Transplanting & Onset (June) & & & & & \\
\hline time & Middle (July) & $47.09^{\mathrm{a}}$ & $37.89^{\mathrm{a}}$ & $37.94^{\mathrm{a}}$ & $40.31^{\mathrm{a}}$ & $44.17^{\mathrm{a}}$ \\
\hline & End (August) & $58.22^{b}$ & $52.49^{b}$ & $45.3^{\mathrm{b}}$ & $42.19^{\mathrm{a}}$ & $40.60^{\mathrm{a}}$ \\
\hline & LSD & 7.5 & 6.38 & 4.65 & 4.75 & 4.81 \\
\hline \multirow[t]{3}{*}{ Variety } & Melkasalsa & $48.82^{\mathrm{a}}$ & $42.49^{\mathrm{a}}$ & $41.25^{\mathrm{a}}$ & $43.38^{b}$ & $46.21^{b}$ \\
\hline & Melkashola & $54.47^{\mathrm{a}}$ & $45.18^{\mathrm{a}}$ & $40.23^{\mathrm{a}}$ & $38.05^{\mathrm{a}}$ & $39.89^{\mathrm{a}}$ \\
\hline & LSD & 6.12 & 5.21 & 3.8 & 3.88 & 3.93 \\
\hline Interaction & $\mathrm{T} * \mathrm{~V}$ & NS & NS & NS & NS & NS \\
\hline \multirow[t]{3}{*}{ Year } & 2015 & $47.43^{\mathrm{a}}$ & $40.85^{\mathrm{a}}$ & $38.76^{\mathrm{a}}$ & $38.719^{\mathrm{a}}$ & $40.857^{\mathrm{a}}$ \\
\hline & 2016 & $55.86^{b}$ & $46.82^{b}$ & $42.72^{\mathrm{b}}$ & $42.715^{b}$ & $45.241^{\mathrm{b}}$ \\
\hline & LSD & 6.12 & 5.12 & 3.8 & 3.88 & 3.93 \\
\hline \multirow[t]{4}{*}{ Interaction } & $\mathrm{Y}^{*} \mathrm{~V}$ & NS & NS & NS & NS & NS \\
\hline & $\mathrm{Y} * \mathrm{~T}$ & $\mathrm{NS}$ & NS & NS & NS & $\mathrm{S}$ \\
\hline & $\mathrm{Y} * \mathrm{~T} * \mathrm{~V}$ & NS & NS & NS & Ns & NS \\
\hline & $\mathrm{CV} \%$ & 17.15 & 17.19 & 13.48 & 13.79 & 13.20 \\
\hline
\end{tabular}

Means in a column followed by different letter within a treatment group are significantly different at $\mathrm{P}<0.05$

From the total yield in 2015, the highest percentage nonmarketable tomatoes were obtained from variety Melkasalsa (45.24\%) ( Figure 2). Significantly higher percentage nonmarketable tomato yield 
was recorded in 2016 than in 2015. Planting periods and variety are therefore among a myriad of factor affecting yield and quality of tomatoes.

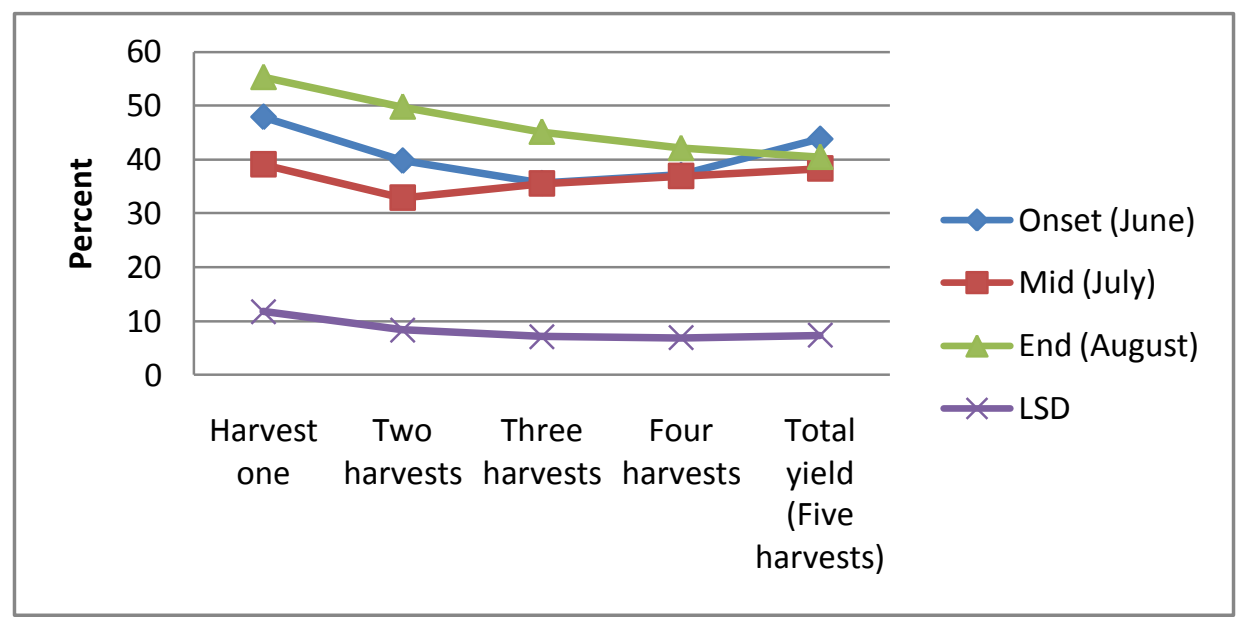

Figure 1. Percentage nonmarketable yield in 2015 rainy season

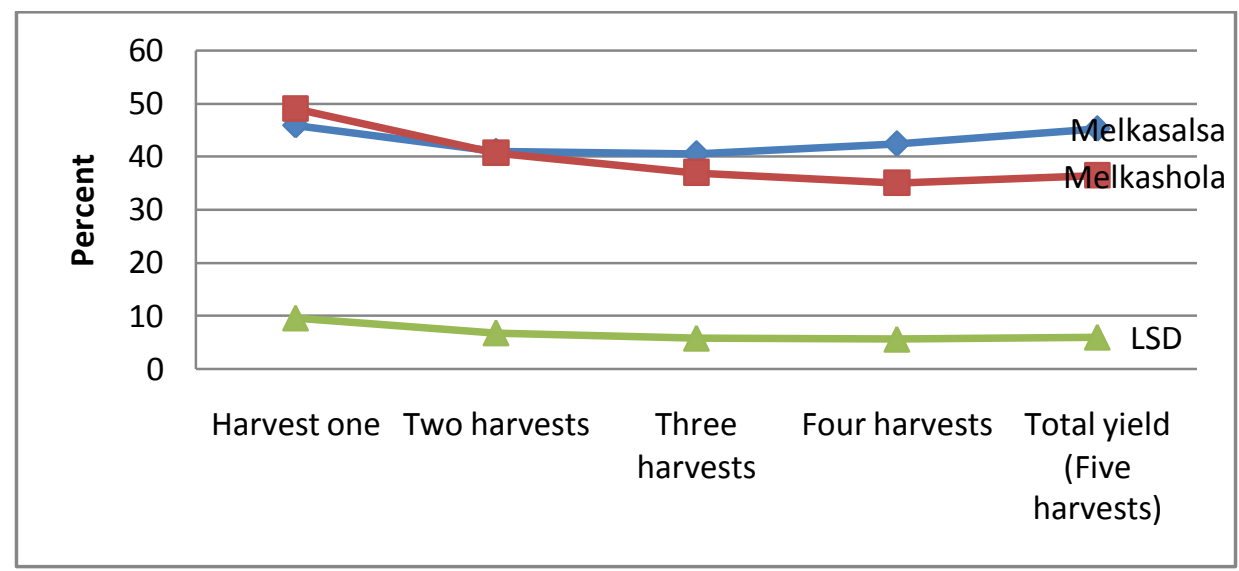

Figure 2. Percentage non marketable yield in 2015 rainy season ( $C V=19.3,15,95,14.37,13,91$ and 14.07\% for harvest one, two harvests, three, four and five harvests, respectively)

Over all result indicated that significantly high percentage nonmarketable tomato yield was obtained from variety Melkasalsa for the last four and five total harvests. On the other hand, variety Melkashola had high nonmarketable fruits in the first two harvests (Table 4), although it is not significantly different from variety Melkasalsa $(\mathrm{P}<0.05)$. Likewise transplanting period in August (in the end of the rainy season) had high percentage nonmarketable tomato fruits for all harvests except the total yield (sum of five harvests). Percentage nonmarketable yield was high in the first harvest largely due to premature fruit drop. Percentage nonmarketable yield went down with successive harvests and finally rose up in the final harvest (Figure 1, 2, 3 and 4). Causes for nonmarketable tomato yield in the final harvest were fruit borer, sun scald and undersized fruits.

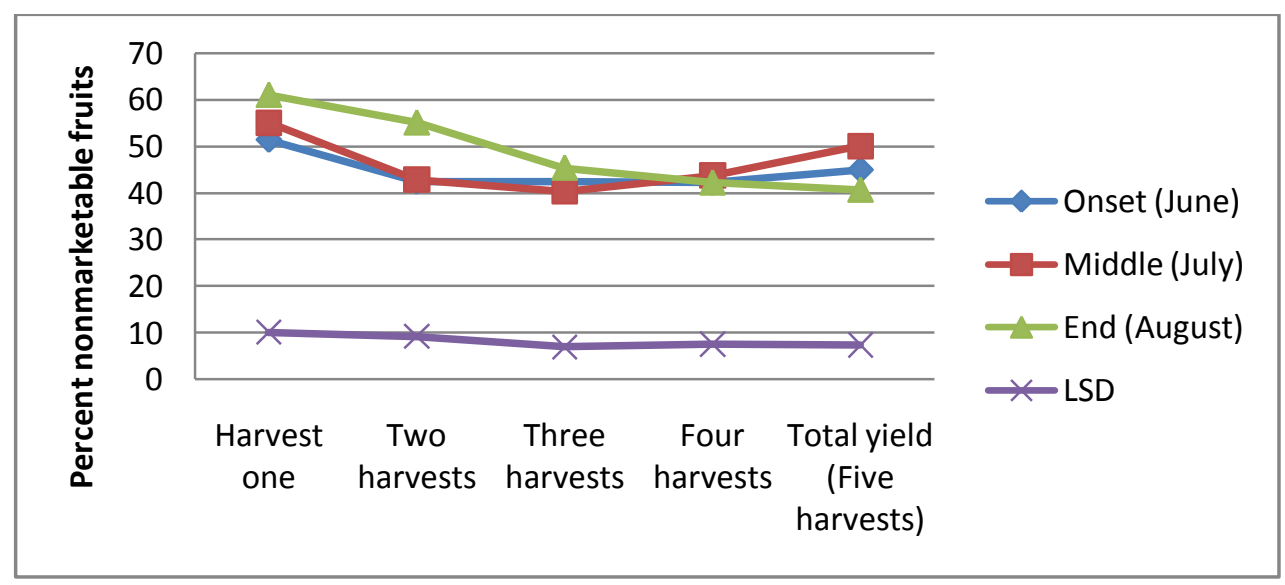

Figure 3. Percentage nonmarketable yield in 2016 rainy season. 


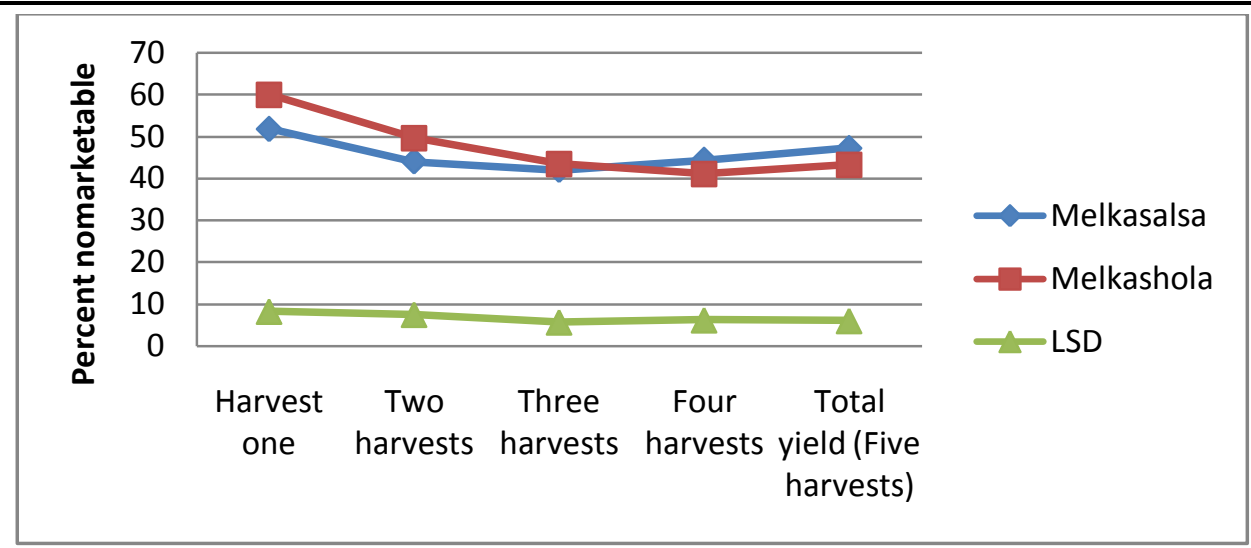

Figure 4. Percentage nonmarketable yield in 2016 rainy season $(C V \%=14.13,15.35,12.76,13.88$ and 12.73 for harvest one, two harvests, three, four and five harvests, respectively).

\section{CONCluSion}

Vital differences in planting periods and tomato varieties in producing marketable fresh as well as nonmarketable tomatoes were observed. Consistently high early harvest was obtained from variety Melkasalsa than Melkashola indicating the earliness in attaining maturity of the former variety. Overall result revealed that transplanting in the middle of the rainy season (July) followed by transplanting in the onset of the rainy season (June) yielded high marketable fresh tomatoes. When compared with yield in 2015 rainy season, marketable yield was generally low in 2016. Moreover, percentage nonmarketable yield was high in 2016. This was largely due to heavy rainfall in 2016 favoring disease development and causing premature fruit drop. The other reason is cold temperature in 2016 as compared with 2015. Since tomato is a warm season crop that enjoys sunlight and high temperature, growth and yield is restricted by cold climatic conditions. Rain fed tomato production in an open field exhibited high fruit loss due primarily to premature fruit drop, rotting due to diseases, sunscald and fruit borer. In addition to increasing productivity and improving fruit quality, further studies need to focus on minimizing the proportion of nonmarketable tomato yield. To ensure continuous production and supply of fresh tomatoes throughout the year, tomatoes can therefore be produced even in the rainy seasons.

\section{REFERENCES}

[1] ARC (2013). Production Guideline for summer vegetables, Agricultural Research Council (ARC), Vegetable and ornamental plant Institute Production, Pretoria, South Africa

[2] Davis, JM and Estes, EA (1993). Spacing and pruning affect growth, yield, and economic return of staked frech-market tomatoes, Journal of American society of horticulture science, 118(6):719-725

[3] Getahun D (2015). Open Field Performance of Tomato (Lycopersicon esculentum Mill.) Varietys in the Rainy Season at Woreta, South Gondar, Ethiopia. International Journal of Scientific Research in Agricultural Sciences, 2(5), pp.17-125.

[4] Greenwald P (2013) Tomatoes, cool rainy weather, and late blight: the perfect storm.

[5] Ibitoye, DO, Akin-Idowu, PE and Ademoyegun, OT (2009). Agronomic and lycopene evaluation in tomato (Lycopersicon lycopersicum Mill.) as a function of genotype, World Journal of Agricultural Sciences, 5, pp. 892-895.

[6] Kirimi JK, Itulya, FM and Mwaja, VN (2011). Effects of nitrogen and spacing on fruit yield of tomato, Afr. J. Hort. Sci. 5:50-60.

[7] Kris (2010). Growing Tomatoes in the Tropics, Garden Doctor at www.BaliAdvertiser.biz

[8] Muhammad A. \& Singh A. (2007). Intra-row spacing and pruning effects on fresh tomato yield in Sudan Savannah of Nigeria. Journal of Plant sciences, 2:153-161.

[9] Panday, KK, Panday, PK and Mishira, KK (2005). Development and testing of an integrated disease management package for multiple disease of tomato, Indian Phytopath, $\quad$ 58(3):294297. 
[10] Shamiyeh NB, Smith AB \& Mullins, CA (2001). Control of early and late blight in tomatoes. http:/bioengr.ag.utk.edu/ExtProg/Vegetable

[11] Tabasi A, Nemati H, and Akbari M (2013). The Effects of Planting Distances and Different Stages of Maturity on the Quality of Three Varietys of Tomatoes (Lycopersicon esculentum Mill) NotSciBiol, 2013, 5(3):371-375

[12] Trinklein, H. David. (2010). Growing home garden tomatoes. University of Missouri Extension: http:/extension.missouri.edu/p/G6461 